\title{
Pengaruh Penerapan Metode Demonstrasi Terhadap Kemampuan Motorik Halus Anak Usia 5 - 6 Tahun di PAUD Harapan Kita
}

Received : 23 April 2020

Revised : 20 Mei 2020

Accepted : 2 Juni 2020

\author{
Ardianti Surya Ningsih ${ }^{1}$, Dorlince Simatupang ${ }^{2}$ \\ Fakultas Ilmu Pendidikan \\ Universitas Negeri Medan \\ Jln. Willem Iskandar Psr V Medan Estate \\ E-mail : $\underline{\text { ardiantiningsih@gmail.com }}$
}

\begin{abstract}
Abstrak. Permasalahan dalam penelitian ini adalah perkembangan motorik halus anak usia 5-6 tahun masih kurang berkembang khususnya dalam mewarnai dan menempel gambar. Oleh karena itu perlu menggunakan metode yang tepat, salah satunya metode demontrasi. Penelitian ini bertujuan untuk mengetahui pengaruh metode demontrasi terhadap perkembangan motorik halus anak usia 5-6 tahun di Paud Harapan KitaT.A 2016/2017.

Metode penelitian ini termasuk penelitian eksperimen yaitu only-post test control grup design. Penelitian ini melibatkan dua kelas sampel yaitu kelas eksperimen dan kelas kontrol dengan jumlah sampel sebanyak 62 anak, yang terdiri dari 31 anak di kelas eksperimen dan 31 anak di kelas kontrol. Instrumen penelitian ini menggunakan lembar observasi.

Berdasarkan hasil penelitian dan pembahasan diperoleh rata-rata nilai pada kelas eksperimen 14,16 dengan nilai tertinggi 16 dan nilai terendah 11, sehingga perkembangan motorik halus anak pada kelas eksperimen lebih baik dibanding kelas kontrol yang mempunyai nilai rata-rata 11,19 dengan nilai tertinggi 13 dan nilai terendah 11 . Berdasarkan hasil tersebut hipotesis menyatakan bahwa pembelajaran menggunakan metode demontrasi berpengaruh secara signifikan terhadap perkembangan motorik halus anak yaitu dari hasil uji hipotesis diperoleh $t_{\text {hitung }}>t_{\text {tabel }}$ yaitu 8,427 $>1,6749$ pada taraf $\alpha$ $=0.05$. Dengan demikian hipotesis Ho ditolak dan Ha diterima sehingga dapat dinyatakan : Ada Pengaruh Yang Signifikan Dari Metode Demontrasi Terhadap Perkembangan Motorik Halus Anak Usia 5-6 Tahun Di Paud Harapan Kita Tahun Ajaran 2017/2018.

Dengan demikian dapat ditarik kesimpulan bahwa pembelajaran dengan menerapkan metode demontrasi mampu memberikan peningkatan terhadap perkembangan motorik halus anak.
\end{abstract}

Kata Kunci: Demonstrasi, Motorik Halus

\section{PENDAHULUAN}

Berdasarkan beberapa pendapat ahli diatas dapat disimpulkan bahwa kemampuan motorik halus adalah pengorganisasian penggunaan otot-otot kecil seperti jari-jemari, tangan dan pergelangan tangan yang membutuhkan koordinasi antara mata dan tangan dalam melakukan suatu aktivitas seperti menggunting, melipat, mewarnai,dan menggambar.

Proses tumbuh kembang kemampuan gerak anak disebut perkembangan motorik. Hurlock (2002) mengatakan "perkembangan motorik berarti perkembangan pengendalian gerakan jasmaniah melalui kegiatan pusat syaraf, urat syaraf, dan otot yang terkoordinasi".Perkembangan motorik diartikan sebagai perkembangan dari unsur kematangan dan pengendalian gerak tubuh, dan perkembangan ini erat kaitannya dengan 
perkembangan pusat motorik di otak. Hal ini sesuai dengan pendapat Yudha dan Rudyanto (2005:118), menyatakan bahwa motorik halus adalah kemampuan anak beraktivitas dengan menggunakan otot halus (kecil) seperti menulis, meremas, menggambar, menyusun balok dan memasukkan kelereng.

Dari tingkat pencapaian diatas penulis menyimpulkan dalam penelitian ini menggunakan tingkat pencapaian perkembangan motorik halus anak usia 5-6 tahun menurut permen 137 tahun 2014. Penelitian ini menggunakan tingkat pencapaian perkembangan no.1 yaitu menggambar sesuai gagasannya yang terdiri dari empat indicator, antara lain: 1) menggambar bebas dengan berbagai media, 2) menggambar bebas dari bentuk dasar titik garis, 3) menggambar orang dengan lengkap dan proporsional, 4) mencetak dengan berbagai media.

Menurut Muhibbin Syah (2006: 208) demonstrasi adalah metode mengajar dengan cara memperagakan barang, kejadian, aturan dan urutan melakukan kegiatan, baik secara langsung maupun melalui penggunaan media pengajaran yang relevan dengan pokok bahasan atau materi yang sedang disajikan. Demonstrasi dapat dilakukan dengan menunjukkan benda baik yang sebenarnya, model, maupun tiruannya dan disertai dengan penjelasan lisan. Demonstrasi akan menjadi aktif jika dilakukan dengan baik oleh guru dan selanjutnya dilakukan oleh siswa. Metode ini dapat dilakukan untuk kegiatan yang alatnya terbatas tetapi akan dilakukan terus-menerus dan berulang-ulang oleh siswa.

Dari beberapa pendapat para ahli di atas dapat disimpulkan bahwa metode demonstrasi merupakan metode penyajian pelajaran dengan memperagakan dan mempertunjukkan kepada anak tentang cara melakukan suatu kegiatan pembelajaran, sesuai dengan tahapan dalam melakukan suatu aktivitas hingga mencapai hasil.

\section{METODOLOGI PENELITIAN}

Metode penelitian yang digunakan dalam penelitian ini adalah metode penelitian eksperimen.Desain dalam penelitian ini adalah True EksperimentalDesign, dengan bentuk Postest-Only Control Design dalam model ini terdapat kelompok eksperimen dan kelompok Kontrol yang dipilih secara random. Sugiyono (2010:117) mengatakan populasi adalah wilayah generalisasi yang terdiri atas : objek/subjek yang mempunyai kualitas dan karakteristik tertentu yang ditetapkan peneliti untuk dipelajari dan kemudian ditarik kesimpulannya. Dari definisi diatas, maka populasi dalam penelitian ini adalah seluruh anak di Paud Harapan Kita yang berjumlah 30 anak, yangterdiri dari 2 kelas yaitu $\mathrm{B}_{1}$ berjumlah 15 anak, $\mathrm{B}_{2}$ berjumlah 15 anak

Dalam penelitian ini teknik pengumpulan data yang digunakan adalah observasi. Metode observasi dilakukan dengan cara mengamati dan mencatat semua aktivitas anak pada proses kegiatan kolase di kelas. Observasi dilakukan pada anakkelompok Buntuk memperoleh data anak yang berkaitan dengan aspek-aspek kreativitas anak.Penyusunan data dilakukan dengan memuat namaanak. Tugas observer memberi tanda checklist $(\checkmark)$ pada skor yang di dapat melalui pedoman observasi yang dibuat. Dari observasi yang dilakukan maka diperoleh data tentang pengaruh darikegiatan kolase ampas kelapa terhadap kreativitas anak usia 5-6 tahun. 
Tabel.1. Kisi-Kisi Lembar Observasi Kemampuan Motorik HalusAnak

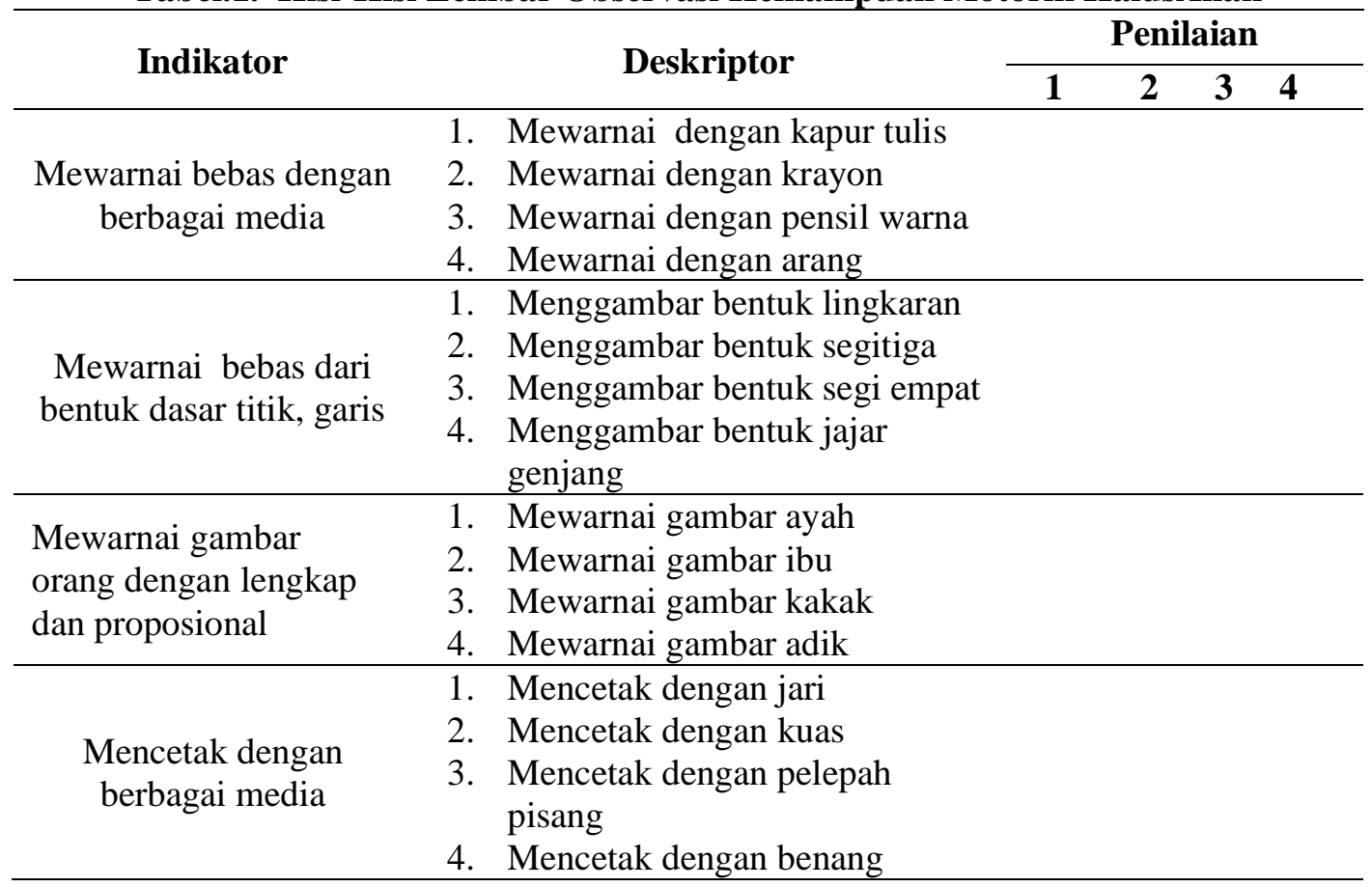

Petunjuk :

$1=$ jika satu descriptor tampak (belum berkembang)

$2=$ jika dua descriptor tampak (mulai berkembang)

$3=$ jika tiga descriptor tampak (berkembang)

$4=$ jika empat descriptor tampak (sangat berkembang)

\section{HASIL DAN DISKUSI}

Telah diterangkan sebelumnya pada bab III bahwa dalam penelitian ini dikumpulkan dengan teknik observasi. Lembar observasi telah disusun sehingga dapat digunakan untuk melihat data perkembangan kreativitas anak.

Dari observasi, dapat dilihat bahwa dengan kegiatan membatik memberikan perbedaan pada perkembangan kreativitas anak di kelas kontrol dan kelas eksperimen. Perbedaan tersebut dapat dilihat dalam tabel dibawah ini 
Tabel 2. Perbedaan Hasil Data Kelas Eksperimen dan Kelas Kontrol

\begin{tabular}{lcclcc}
\hline & Kelas Ekperimen & \multicolumn{3}{c}{ Kelas Kontrol } \\
\hline No & Nilai Observasi Akhir & Frekuensi & No & Nilai Observasi Akhir & Frekuensi \\
\hline 1. & 11.5 & 6 & 1. & 8.5 & 4 \\
\hline 2. & 12.5 & 3 & 2. & 9.5 & 4 \\
\hline 3. & 13.5 & 9 & 3. & 12.9 & 10 \\
\hline 4. & 19.3 & 6 & 4. & 32.5 & 8 \\
\hline 5. & 22.5 & 7 & 5. & 25.80 \\
\hline Jumlah & $\mathbf{3 1}$ & Jumlah & $\mathbf{3 1}$ \\
\hline Rata-rata $=\mathbf{1 4 . 1 6}$ & \multicolumn{5}{l}{ Rata-rata = 11,19 } \\
\hline Simpangan Baku $=\mathbf{1 . 4 1}$ & \multicolumn{5}{l}{ Simpangan Baku = 1,24 } \\
\hline
\end{tabular}

Dari tabel diatas dapat dilihat bahwa ada perbedaan antara kelas eksperimen dan kelas kontrol. Pada kelas Eksperimen jumlah frekuensinya adalah 40, dengan nilai rata-rata 14.16 dan simpangan baku 1,41. Dikelas kontrol jumlah frekuensi 31 dengan nilai ratarata 11.19 dan simpangan baku 1,24. Dari hasil analisis data peneliti dapat dijelaskan bahwa kemampuan motorik halus anak yang dibelajarkan dengan menggunakan metode demontrasi lebih baik dibandingkan dengan anak yang dibelajarkan dengan metode peroyek.

\section{PEMBAHASAN}

Penerapan metode demontrasi membuat kemampuan motorik halus anak semakin meningkat, hal ini dikarenakan metode demontrasi merupakan metode yang pengajarannya praktek secara langsung. Hal ini sesuai dengan pendapat Muhibbin Syah (2006:208) demontrasi adalah "metode mengajar dengan cara memperagakan barang, kejadian aturan dan urutan melakukan kegiatan, baik secara langsung maupun melalui penggunaan media pengajaran yang relevan dengan pokok bahasan atau materi yang sedang disajikan".

Melalui metode demontrasi anak bisa diajak secara langsung dalam menjelaskan informasi kepada anak. Sedangkan metode proyek dikelas kontrol kurang memuaskan. Hal ini terlihat saat anak disuruh mewarnai dan menempel, hanya sebagian anak yang mewarnai dengan rapi dan menempel sesuai perintah guru.

Dengan demikian, berdasarkan hasil penelitian yang telah dilakukan di Paud Harapan Kita Sawit Seberang kemampuan mlotorik halus anak dikelas eksperimen lebih baik dibandingkan dikelas kontrol. Dapat disimpulkan bahwa metode demontrasi memilki pengaruh yang signifikan terhadap kemampuan motorik halus anak di Paud Harapan Kita Sawit Seberang. 


\section{SIMPULAN}

Berdasarkan hasil penelitian dan pengolahan data pada sub bab sebelumnya dapat di ambil kesimpulan, yaitu :

1. Metode demontasi adalah metode penyajian pelajaran dengan memperagakan dan mempertunjukkan kepada anak tentang cara melakukan suatu kegiatan pembelajaran, sesuai dengan tahapan dalam melakukan suatu aktivitas hingga mencapai hasil.

2. Penerapan metode demontrasi memberikan pengaruh signifikan terhadap kemampuan motorik halus anak dibandingkan dengan menggunakan metode proyek.

3. Hasil nilai nuji hipotesa terbukti bahwa $t_{\text {hitung }}>t_{\text {tabel }}(8,427>1,749$. Hal tersebut sesuai dengan hipotesis Ho ditolak Ha diterima, sehingga dapat dinyatakan "Ada pengaruh yang signifikan antara metode demontrasi terhadap kemampuan motorik halus anak usia 5-6 tahun di Paud Harapan Kita Sawit Seberang T.A 2016/2017".

Berdasarkan kesimpulan diatas, maka peneliti mengajukan beberapa saran yaitu :

1. Bagi kepala sekolah hendaknya menghimbau dan member kesempatan kepada guru untuk mengikuti pelatihan dan menyediakan media yang di buat dalam pembelajaran motorik halus anak.

2. Bagi guru hendaknya dalam melakukan proses pembelajaran yang mengenal motorik halus anak untuk menarik minat anak untuk belajar dengan menggunakan metode demonstrasi agar menoingkatkan kemampuan motorik halus anak.

3. Bagi peneliti menambah wawasan dan ilmu pengetahuan tentang apa yang telah dikaji sehingga nanti akan lebih mudah menggunakan metode demontrasi saat proses belajar anak.

\section{DAFTAR RUJUKAN}

Djamarah Bahri Syaiful \& Zain Aswan. 2011. Strategi Belajar Mengajar: Jakarta: Rineka Cipta.

Fadlina. 2012. Jurnal Pengaruh Metode Demonstrasi Terhadap Perkembangan Motorik Halus Anak. Palu.: Universitas Tadulako.

Gunarti Winda, Suryani Lilis \& Muis. 2014. Metode Pengembangan Perilaku Dan Kemampuan Dasar Anak Usia Dini. Tangerang Selatan. Universitas Terbuka.

Hurlock, Elizabeth B. 2002. Psikologi Perkembangan Suatu Pendekatan Sepanjang Rentang Usia. Jakarta: Erlangga.

Isjoni. 2010. Model Pembelajaran Anak Usia Dini. Membentuk Generasi Cemerlang Harapan Bangsa. Alfabeta. Bandung.

Istarani. 2012. Kumpulan 39 Model Pembelajaran Untuk Revolusi Pengajaran. Medan: CV. Iscom.

Moedjiono. 2005. Proses Belajar Mengajar. Jakarta: Rosda.

R. Moeslichatoen. 2004. Metode Pengajaran Di Taman Kanak-Kanak. Kencana. Jakarta.

Roestiyah. 2001. Strategi Belajar Mengajar. Jakarta: PT. Rineka Cipta.

Sagala, Syaiful, Syawal Gultom. 2011. Praktik Etika Pendidikan Di Seluruh Wilayah NKRI. Bandung.: Alfabeta.

Sanjaya Wina. 2010. Strategi Pembelajaran Berorientasi Standar Proses Pendidikan. Jakarta: Kencana. 
Sugiono. 2009. Metode Penelitian Pendidikan Pendekatan Kuantitatif, Kualitatif, dan $R \& I$. Bandung.: Alfabeta.

Sumantri. 2005. Model Pengembangan Keterampilan Motorik Anak Usia Dini. Jakarta: Departemen Pendidikan Nasional.

Susanto, Ahmad. 2011. Perkembangan Anak Usia Dini. Jakarta: Kencana Prenada Media Group.

Suyanto. 2005. Dasar-Dasar Pendidikan AUD. Yogyakarta: Hikayat Publishing. Syah, Muhibbin. 2006. Psikologi Belajar. Jakarta: Rajawali Pers. 